\title{
Quantifying the Acidic and Basic Effects of Fifteen Floriculture Species Grown in Peat-based Substrate
}

\author{
Ryan W. Dickson \\ Department of Animal, Nutrition, and Food Systems, UNH Cooperative \\ Extension, University of New Hampshire, Durham, NH 03824
}

Paul R. Fisher ${ }^{1}$

IFAS, University of Florida, Gainesville, FL 32611

\author{
William R. Argo \\ The Blackmore Company, 10800 Blackmore Avenue, Belleville, MI 48111
}

Additional index words. soilless substrate, iron-efficiency, pH management, acidity, basicity, cluster analysis

\begin{abstract}
Floriculture species differ in their effect on substrate-pH and the resulting substrate micronutrient availability in container production. The objective was to quantify effects of floriculture plant species on substrate-pH. In a growth chamber factorial experiment, 15 floriculture species were grown in $70 \%: 30 \%$ by volume peat: perlite substrate and fertilized with nutrient solutions containing $100 \mathrm{mg} \cdot \mathrm{L}^{-1} \mathrm{~N}$ and $\mathrm{NH}_{4}{ }^{+} \mathrm{N}: \mathrm{NO}_{3}{ }^{-}-\mathrm{N}$ nitrogen ratios of $0: 100,20: 80$, or 40:60. The relationship between substrate-pH and milliequivalents (meq) of acid or base per unit volume of substrate was quantified by titration with hydrated dolomitic lime or HCl. After 33 days, species and solution type effects on substrate-pH and estimated meq of acid or base produced were evaluated. Final substrate-pH ranged from 4.83 for geranium in 40:60 solution to 6.58 for lisianthus in 0:100 solution, compared with an initial substrate-pH of 5.84. This change in substrate-pH corresponded with a net meq of acid or base produced per gram of tissue dry mass gain (NMEQ) ranging across solutions and species from 1.47 of base for lisianthus in the 0:100 solution to 2.10 of acid for coleus in the 40:60 solution. With the 0:100 solution, geranium produced the greatest NMEQ of acid $(0.07)$, whereas lisianthus produced the greatest NMEQ of base (1.47). Because all $N$ in the $0: 100$ solution was in the $\mathrm{NO}_{3}{ }^{-}$anion form, meq of both anions and cations taken up by plant roots could be calculated based on tissue analysis. With the 0:100 solution, species that took up more anions than cations into plant tissue tended to have a more basic effect on substrate-pH, as would be expected to maintain electroneutrality. Data were used to estimate the percent $\mathrm{NH}_{4}{ }^{+} \mathrm{N}$ of total $\mathrm{N}$ in a nutrient solution that would be neutral (results in no substrate-pH change) for each species. This neutral percent $\mathrm{NH}_{4}{ }^{+}-\mathrm{N}$ of total $\mathrm{N}$ ranged from $\approx 0 \%$ (geranium) to $35 \%$ (pentas). Species were separated into three clusters using $k$-means cluster analysis with variables related to NMEQ and anion or cation uptake. Species were clustered into groups that had acidic (geranium and coleus), intermediate (dusty miller, impatiens, marigold, new guinea impatiens, petunia, salvia, snapdragon, and verbena), or basic (lisianthus, pansy, pentas, vinca, and zinnia) effects on substratepH. Evaluating the tendency to increase or decrease substrate-pH across a range of floriculture species, and grouping of plants with similar $\mathrm{pH}$ effects, could help predict $\mathrm{NH}_{4}{ }^{+}: \mathrm{NO}_{3}{ }^{-}$ratios for a neutral $\mathrm{pH}$ effect and assist growers in managing substrate-pH for container production.
\end{abstract}

Controlling $\mathrm{pH}$ in soilless substrate is critical to managing nutrient availability in container production (Peterson, 1981). This can be a challenge considering that several

\footnotetext{
Received for publication 8 Mar. 2017. Accepted for publication 6 July 2017.

We thank PanAmerican Seed, USDA-ARS Floriculture and Nursery Research Initiative \#58-3607-8-725, and industry partners of the Floriculture Research Alliance at the University of Florida (floriculturealliance. org) for supporting this research. Thanks to James Colee from the Department of Statistics at University of Florida IFAS for providing statistical support. ${ }^{1}$ Corresponding author. E-mail: pfisher@ufl.edu.
}

Barnes et al., 2014; Haynes, 1990; Huang et al., 2001; Johnson et al., 2013; Marschner, 2012). Fertilization with ammonium nitrogen $\left(\mathrm{NH}_{4}{ }^{+}-\mathrm{N}\right)$ produces an acidic reaction that decreases $\mathrm{pH}$ as a result of $\mathrm{H}^{+}$efflux from roots during uptake and from nitrification. Nitrification can occur rapidly in container substrate above $\mathrm{pH} 5.5$ and depends on factors that affect microbial activity such as $\mathrm{pH}$, temperature, oxygen, moisture, crop duration, substrate components, nitrogen form, and concentration (Argo and Biernbaum, 1997; Lang and Elliot, 1991). Fertilization with nitrate nitrogen $\left(\mathrm{NO}_{3}{ }^{-}-\mathrm{N}\right)$ usually produces a basic reaction that increases $\mathrm{pH}$, resulting from the efflux of hydroxyl $\left(\mathrm{OH}^{-}\right)$or bicarbonate $\left(\mathrm{HCO}_{3}{ }^{-}\right)$ions from roots (Haynes, 1990; Marschner, 2012). Ammonium typically has a greater impact on substrate-pH compared with $\mathrm{NO}_{3}{ }^{-}-\mathrm{N}$ when both forms are applied because $\mathrm{NH}_{4}{ }^{+}-\mathrm{N}$ uptake is energetically favored over $\mathrm{NO}_{3}{ }^{-} \mathrm{N}$ uptake (Engels and Marschner, 1995; von Wiren et al., 2001). The effect of urea nitrogen (urea-N) on substrate-pH varies depending on the state of hydrolysis, nitrification, and the subsequent uptake of $\mathrm{NH}_{4}{ }^{+}-\mathrm{N}$ vs. $\mathrm{NO}_{3}{ }^{-}-\mathrm{N}$ (Verburg et al., 2003).

Floriculture species differ in their effect on substrate- $\mathrm{pH}$, even when supplied with the same water-soluble fertilizer (Huang et al., 2001; Johnson et al., 2013). Huang et al. (2001) showed that seedlings of pansy (Viola ×wittrockiana Gams.), petunia (Petunia $\times$ hybrid Vilm.-Andr.), and vinca (Catharanthus roseus G. Don.) increased the $\mathrm{pH}$ whereas celosia (Celosia cristata L.) and zinnia (Zinnia elegans Jacq.) decreased the $\mathrm{pH}$ in peat: perlite substrate. In both substrate (Johnson et al., 2013) and hydroponic nutrient solution (Dickson et al., 2016), geranium (Pelargonium $\times$ hortorum Bailey L.H.) was acidic and decreased the $\mathrm{pH}$ compared with petunia which was basic and increased the $\mathrm{pH}$, whereas impatiens (Impatiens wallerana Hook. F.) had intermediate effects to geranium and petunia.

A major process by which plants affect root zone $\mathrm{pH}$ is through imbalanced uptake of cation and anion nutrients (Haynes, 1990; Lea-Cox et al., 1996; Marschner, 2012; Rengel, 2003). Roots maintain charge balance either by equal uptake of cations and anions or by the efflux of ions equal to the net charge taken up by roots. Net cation uptake is balanced by efflux of $\mathrm{H}^{+}$ions whereas net anion uptake is balanced by efflux of $\mathrm{OH}^{-}$or $\mathrm{HCO}_{3}{ }^{-}$from roots (Kirkby and Knight, 1977; Lea-Cox et al., 1996; Marschner, 2012).

Some agronomic crop species that are labeled "iron-efficient" acidify the root zone as a strategy to improve iron solubility and uptake when grown in calcareous soil (Marschner, 2012). Geranium is a floriculture species that is referred to as "iron-efficient" because of high susceptibility to iron or manganese toxicity at low $\mathrm{pH}$ and also has the tendency to decrease substrate-pH over time (Argo and Fisher, 2002; Johnson et al., 2013). Other floriculture species susceptible to iron or manganese toxicity may also 
decrease $\mathrm{pH}$, possibly as a means to increase iron uptake.

Johnson et al. (2013) modeled the interaction between three floriculture species (geranium, impatiens, and petunia) fertilized with 18 water-soluble fertilizers differing in applied nitrogen forms $\left(\mathrm{NH}_{4}{ }^{+}-\mathrm{N}, \mathrm{NO}_{3}{ }^{-} \mathrm{N}\right.$, and urea-N) and concentration. The acidity or basicity of a fertilizer could be manipulated by adjusting nitrogen forms and concentrations to balance species root zone effects and stabilize $\mathrm{pH}$. For example, the model predicted that geranium, impatiens, and petunia would require $0 \%, 10 \%$, and $31 \%$ of total $\mathrm{N}$ as $\mathrm{NH}_{4}{ }^{+}-\mathrm{N}$, respectively, with the remainder of $\mathrm{N}^{4} \mathrm{NO}_{3}{ }^{-}-\mathrm{N}$. This ratio would be expected to maintain a stable $\mathrm{pH}$ over time when these species were grown with zero alkalinity irrigation water and without residual lime in the substrate.

Commercial bedding plant operations typically grow a wide range of plant species, often in the same greenhouse, that may differ in effects on substrate-pH. Species diversity is therefore an important consideration in $\mathrm{pH}$ management. However, it is also not feasible to provide separate fertilizer regimes to hundreds of cultivars grown at a single location, and grouping of plants is necessary. The objective was to quantify the effects of plant species on substrate-pH for floriculture species fertilized with different $\mathrm{NH}_{4}: \mathrm{NO}_{3}$ nitrogen ratios. Floriculture species common in container production were selected, where species also differed in reported susceptibility to iron or manganese deficiency or toxicity and optimum pH (Argo and Fisher, 2002; Whipker et al., 2003).

The objective of this study was to quantify effects of floriculture plant species on substrate-pH. In a factorial experiment conducted in a controlled environment growth chamber, 15 floriculture species were grown in peat:perlite substrate and were irrigated with modified $0.5 \times$ Hoagland's nutrient solutions with $\mathrm{NH}_{4}{ }^{+}: \mathrm{NO}_{3}{ }^{-}$nitrogen ratios of $0: 100,20: 80$, and 40:60. After $33 \mathrm{~d}$, substrate-pH was measured and meq of acid or base produced per L of substrate was estimated using an acid-base substrate titration (Johnson et al., 2010). Nitrogen is taken up in different forms that vary in their charge (including $\mathrm{NH}_{4}^{+}$and $\mathrm{NO}_{3}^{-}$), and without isotope labeling (which was not used in this study), total $\mathrm{N}$ level in tissue cannot distinguish between the original fertilizer nutrient form. Dry tissue was harvested from plants irrigated with the 0:100 solution, and tissue nutrient data were used to estimate net uptake of anions minus cations, and cation or anion uptake ratio, assuming that all $\mathrm{N}$ was taken up in the anionic $\mathrm{NO}_{3}^{-}$form. Species and solution $\mathrm{NH}_{4}{ }^{+}: \mathrm{NO}_{3}{ }^{-}$ratio were evaluated for effects on substrate-pH and meq of acid or base produced per L of substrate. Species were separated into clusters that corresponded to species overall acidic, intermediate, and basic effects on substrate- $\mathrm{pH}$, and linear regression was used to predict speciesspecific $\mathrm{NH}_{4}{ }^{+}: \mathrm{NO}_{3}{ }^{-}$ratios expected to result in a stable $\mathrm{pH}$. We hypothesized that species fertilized with $100 \% \mathrm{NO}_{3}{ }^{-}-\mathrm{N}$ that had greater net anion minus cation uptake would result in greater basicity than species that favored cation uptake. We also hypothesized that floriculture species that are reportedly susceptible to iron or manganese toxicity at low $\mathrm{pH}$ may tend to decrease substrate- $\mathrm{pH}$, possibly acidifying the root zone as an ironefficiency mechanism (Marschner, 2012).

\section{Materials and Methods}

The experiment was a factorial randomized complete block design with 15 species and three fertilizer $\mathrm{NH}_{4}{ }^{+}: \mathrm{NO}_{3}{ }^{-}$nitrogen ratios (0:100, 20:40, and 40:60) from a 0.5× Hoagland's solution (Hoagland and Arnon, 1950), supplied at $100 \mathrm{mg} \cdot \mathrm{L}^{-1} \mathrm{~N}$, and organized in six blocks (benches) with 270 total replicate containers. On 5 Feb. 2015, seedling plugs of 15 floriculture species were transplanted from 144-cell trays (supplied by Knox Nursery, Winter Garden, FL) into four-cell plastic bedding plant containers (FG12047, $88 \mathrm{~mL}$ per cell or $350 \mathrm{~mL}$ per container) at four plants per container. Each four-cell container was considered as one replicate.

Plants were grown for $33 \mathrm{~d}$ on benches in a controlled environment growth chamber located at the University of Florida in Gainesville, FL. Growth chamber lighting was supplied by cool white fluorescent bulbs
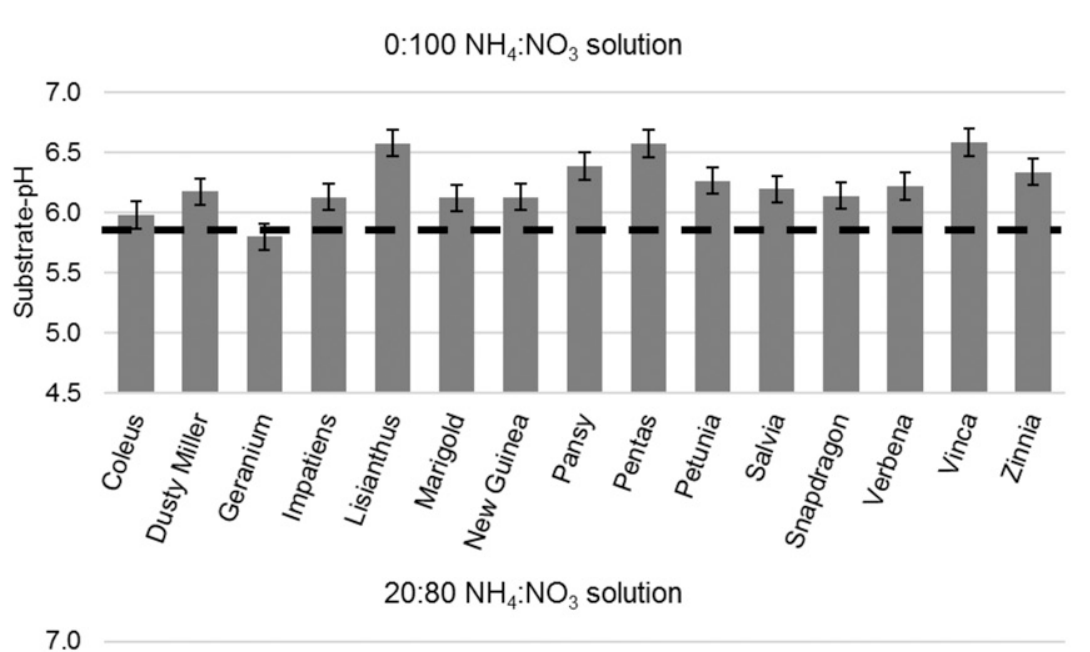

B

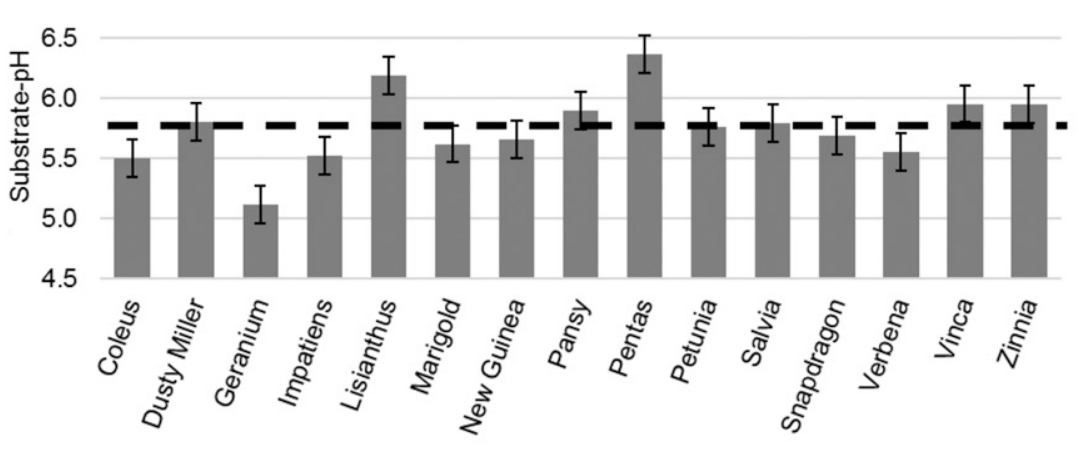

40:60 $\mathrm{NH}_{4}: \mathrm{NO}_{3}$ solution

C

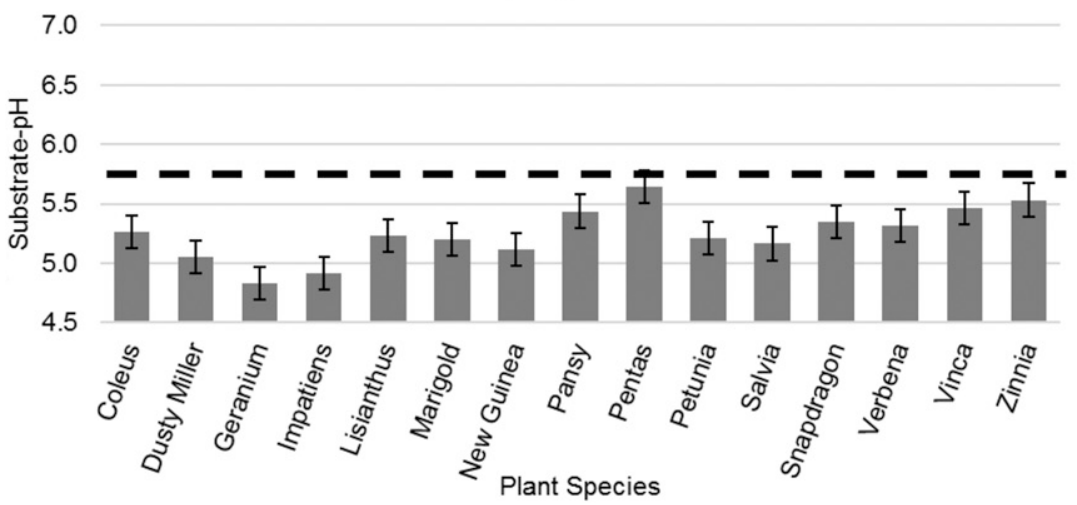

Fig. 1. Substrate-pH after $33 \mathrm{~d}$ for floriculture species grown in peat: perlite substrate and irrigated with nutrient solutions containing $100 \mathrm{mg} \cdot \mathrm{L}^{-1} \mathrm{~N}^{-} \mathrm{nd}_{4}{ }^{+}: \mathrm{NO}_{3}{ }^{-}$nitrogen ratios of (A) $0: 100$, (B) 20:80, and (C) 40:60. Data are species least-square means of six replicates. Error bars indicate $\pm 95 \%$ confidence intervals using Tukey's honestly significant difference at $\alpha=0.05$. Dashed lines represent the initial substrate-pH (5.84) at the beginning of the experiment. 
(32 W, $6500 \mathrm{~K})$. Photosynthetically active radiation was measured at the plant canopy level using a quantum sensor (Apogee Instruments, Inc., Logan, UT), where light intensity averaged $175 \mu \mathrm{mol} \cdot \mathrm{m}^{-2} \cdot \mathrm{s}^{-1}$ for a daily light integral of $11.3 \mathrm{~mol} \cdot \mathrm{m}^{-2} \cdot \mathrm{d}^{-1}$ across species. Daily air and substrate temperatures measured during the experiment with external temperature sensors connected to data loggers (Onset Computer Corporation, Bourne, MA) were $22.5 \pm 1.5{ }^{\circ} \mathrm{C}$ and $23.1 \pm 1.6{ }^{\circ} \mathrm{C}$ (mean $\pm \mathrm{SD}$ ), respectively.

Floriculture species consisted of geranium (Pelargonium $\times$ hortorum Bailey. L.H.) 'Ringo 2000 Deep Red', impatiens (Impatiens wallerana Hook. F.) 'Super Elfin Orange Bright', petunia (Petunia $\times$ hybrid Vilm.-Andr.) 'Ultra Red', coleus (Solenostemon scutellariodes L.) 'Premium Sum Chocolate Covered Cherry', pentas (Pentas lanceolata Forssk.) 'Butterfly Red', snapdragon (Antihirrum majus L.) 'Snapshot Yellow', verbena (Verbena $\times$ hybrida L.) 'Quartz White XP', vinca (Catharanthus roseus L.) 'Titan Dark Red', lisianthus (Eustoma grandiflorum Salisb.) Florida Sky Blue', African marigold (Tagetes erecta L.) 'Taishan Orange', dusty miller (Senecio cineraria L.) 'Maritima Silverdust', pansy (Viola tricolor D.C.) 'Matrix Clear Yellow', salvia (Salvia splendens Sellow ex Roem. \& Schult.) 'Vista Red', New Guinea impatiens (Impatiens hawkeri L.) 'Divine White Blush', and zinnia (Zinnia elegans L.) 'Zahara Double Fire'. Most species had open flowers at the end of the experiment, except for coleus, dusty miller, and lisianthus, which appeared vegetative with no visible flower buds.

The substrate was 70\%:30\% (v:v) peat: perlite mixed at the University of Florida using Canadian Sphagnum peat (Sun Gro Horticulture, Bellevue, WA) with long fibers and little dust (Von Post scale 1-2; Puustjarvi and Robertson, 1975) and wetting agent $\left(0.15 \mathrm{~mL} \cdot \mathrm{L}^{-1}\right.$ of substrate; Aquatrols, Paulsboro, NC). Hydrated dolomitic limestone [Graymont Western Lime, Inc., Eden, WI, 97\% $\mathrm{Ca}(\mathrm{OH})_{2} \cdot \mathrm{MgO}$ of which $92 \%$ passed through a $45-\mu \mathrm{m}$ mesh and had an acid neutralizing value of $140 \%$ calcium carbonate equivalents (CCE)] was incorporated at $1.67 \mathrm{~kg} \cdot \mathrm{m}^{-3}$ of substrate for a $\mathrm{pH}$ of 6.0. Hydrated dolomitic limestone was used to avoid residual lime buffering of substrate-pH after planting.

Plants were fertilized using $0.5 \times$ modified Hoagland's nutrient solutions with $\mathrm{NH}_{4}^{+}$: $\mathrm{NO}_{3}{ }^{-}$nitrogen ratios of $0: 100,20: 80$, and 40:60 mixed with reagent grade salts in zero alkalinity deionized water. Macronutrients were supplied at $100 \mathrm{~N}, 16 \mathrm{P}, 117 \mathrm{~K}, 100$ $\mathrm{Ca}$, and $24 \mathrm{Mg}$ in $\mathrm{mg} \cdot \mathrm{L}^{-1}$. Sulfate and $\mathrm{Cl}$ concentrations varied depending on solution $\mathrm{NH}_{4}{ }^{+}: \mathrm{NO}_{3}{ }^{-}$ratio, and $\mathrm{S}$ and $\mathrm{Cl}$ concentrations were (in $\mathrm{mg} \cdot \mathrm{L}^{-1}$ ) 38 and 0 for the $0: 100$ solution, 61 and 24 for the 20:80 solution, and 113 and 36 for the 40:60 solution, respectively. Macronutrients were derived from $\left(\mathrm{NH}_{4}\right)_{2} \mathrm{SO}_{4} \mathrm{Ca}\left(\mathrm{NO}_{3}\right)_{2} \cdot 4 \mathrm{H}_{2} \mathrm{O},\left(\mathrm{KH}_{2} \mathrm{PO}_{4}\right)$, $\left(\mathrm{MgSO}_{4} \cdot 7 \mathrm{H}_{2} \mathrm{O}\right),\left(\mathrm{CaCl}_{2} \cdot 2 \mathrm{H}_{2} \mathrm{O}\right),\left(\mathrm{KNO}_{3}\right)$, and $\left(\mathrm{K}_{2} \mathrm{SO}_{4}\right)$. Micronutrient concentrations at $100 \mathrm{mg} \cdot \mathrm{L}^{-1} \mathrm{~N}$ were $\left(\mathrm{mg} \cdot \mathrm{L}^{-1}\right) 2 \mathrm{Fe}, 1 \mathrm{Mn}$,
$1 \mathrm{~B}, 0.2 \mathrm{Cu}, 0.5 \mathrm{Zn}$, and 0.04 Mo supplied from FeEDDHA $(6.0 \% \mathrm{Fe}$, Akzo-Nobel, Holland), $\mathrm{CuSO}_{4} \cdot 5 \mathrm{H}_{2} \mathrm{O}, \quad \mathrm{MnSO}_{4} \cdot \mathrm{H}_{2} \mathrm{O}$, $\left(\mathrm{NH}_{4}\right)_{6} \mathrm{MoO}_{2} \cdot 2 \mathrm{H}_{2} \mathrm{O}, \mathrm{H}_{3} \mathrm{BO}_{3}$, and $\mathrm{ZnSO}_{4} \cdot 7 \mathrm{H}_{2} \mathrm{O}$.

At transplant, each replicate container was irrigated to container capacity with 150 $\mathrm{mL}$ of either $0: 100,20: 80$, or 40:60 solution at $200 \mathrm{mg} \cdot \mathrm{L}^{-1} \mathrm{~N}$. The remaining irrigations consisted of $100 \mathrm{~mL}$ at $100 \mathrm{mg} \cdot \mathrm{L}^{-1} \mathrm{~N}$. Plastic liners with gusseted bottoms were secured underneath each replicate container to collect leachate and allow for reabsorption into the substrate. Each replicate received a total of $1.15 \mathrm{~L}$ of nutrient solution during the experiment.

Initial substrate-pH and electrical conductivity (EC) were measured for each solution type on 12 replicate containers without plants using the plug squeeze method of Scoggins et al. (2002). Measurements were taken on the combined leachate squeezed from each of the four cells per replicate container. Initial substrate-pH was measured after the first irrigation at transplant and averaged $5.84 \pm$ 0.04 (mean \pm SD) across all $\mathrm{NH}_{4}^{+}: \mathrm{NO}_{3}$ treatments. Initial substrate EC was $1.98 \pm$ $0.02,2.14 \pm 0.03$, and $2.27 \pm 0.02 \mathrm{mS} \cdot \mathrm{cm}^{-1}$ for $0: 100,20: 80$, and $40: 60 \mathrm{NH}_{4}{ }^{+}: \mathrm{NO}_{3}$ solutions, respectively. Containers used for initial measurements had the same substrate$\mathrm{pH}$ and substrate-EC $14 \mathrm{~d}$ after transplant (data not shown), indicating that substrate$\mathrm{pH}$ and $\mathrm{EC}$ were relatively stable in the absence of plants. Final substrate-pH and EC were measured at the end of the experiment for each treatment replicate.

Species effects on substrate-pH over time were related to meq of acid or base produced per L of substrate using the acid-base titration approach of Johnson et al. (2010). In a laboratory procedure, samples of the same substrate used for the experiment, but not for growing plants, were placed into plastic ziplock bags at $250 \mathrm{~mL}$ of substrate per bag. The substrate in each bag was moistened with $150 \mathrm{~mL}$ of 20:80 nutrient solution at $200 \mathrm{mg} \cdot \mathrm{L}^{-1} \mathrm{~N}$. Hydrochloric acid $(0.5060 \mathrm{~N})$ was added at
$0,2.5,5.0,7.5,10.0$, or $12.5 \mathrm{~mL}$ per sample for an equivalent of $0,10,20,30,40$, and 50 meq of acid added per L of substrate. Hydrated dolomitic lime $(139 \%$ CCE) was added at $0,0.18,0.36,0.54,0.72$, and 0.90 $\mathrm{g}$ per sample for an equivalent of $0,10,20$, 30,40 , and 50 meq of base added per liter of substrate. There were four replicates for each acid and base titration level, and replicates were allowed to equilibrate for 7 days before measuring substrate-pH. A polynomial curve was fit relating the change in $\mathrm{pH}$ units (from initial $\mathrm{pH} 5.84$ ) to the meq of acid or base added per L of substrate, which was used to estimate the meq of acid or base produced by each species when supplied with each of the three solution types.

The uptake of individual nutrients was measured for plants fertilized with the $0: 100$ solution. Root and shoot tissue was harvested from seedlings at the beginning of the experiment and from each final replicate that received the $0: 100$ solution. Tissue was rinsed with $\mathrm{HCl}(0.1 \mathrm{~N})$ followed by deionized water and was oven-dried for $48 \mathrm{~h}$ at $70{ }^{\circ} \mathrm{C}$. Roots were washed with phosphatefree soap before the $\mathrm{HCl}$ rinse to remove substrate particles from root surfaces. Plant growth was measured as total dry mass gain (roots and shoots), which was calculated by subtracting the average dry mass for four seedlings from the final dry mass per replicate for each species (four plants per replicate).

Dry root and shoot tissue from plants supplied with 0:100 solution was analyzed for concentration of macronutrient and micronutrient elements by inductively coupled plasma atomic emission spectrophotometry (Quality Analytical Laboratories, Panama City, FL). Tissue concentrations of macronutrient and micronutrient elements were within the general sufficiency ranges proposed by Vetanovetz (1996) for bedding plants (data not shown). The concentration of each element in the tissue was multiplied by the dry mass to determine the total nutrient

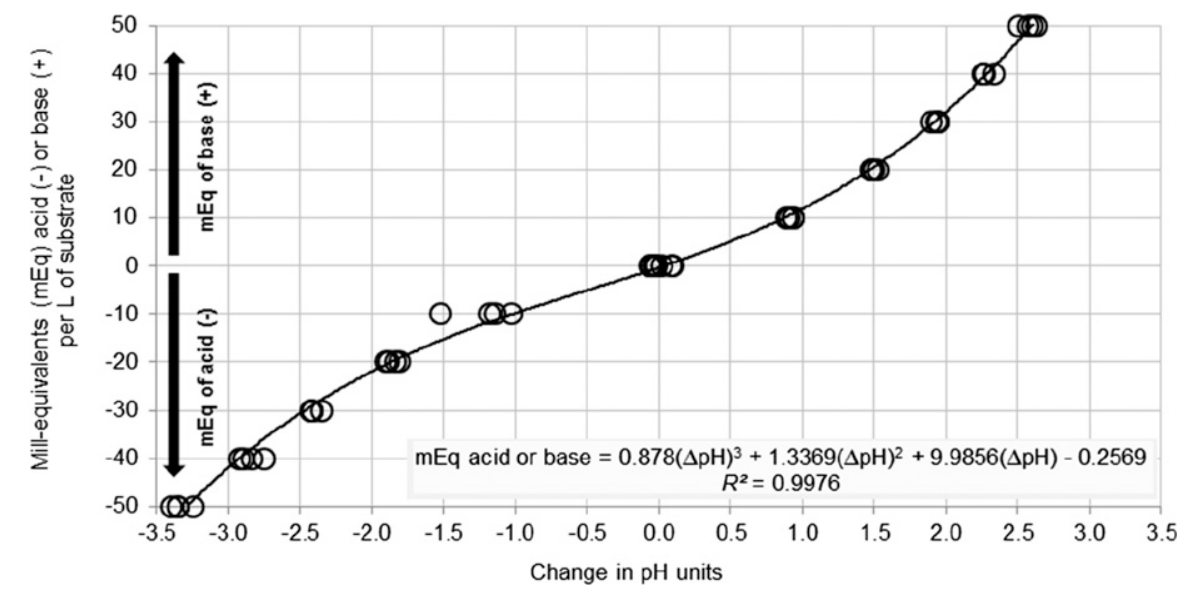

Fig. 2. Relationship between mineral acid $(0.5060 \mathrm{~N}$ hydrochloric acid) or base (hydrated dolomitic limestone with $139 \%$ neutralizing value) and change in substrate- $\mathrm{pH}(\Delta \mathrm{pH})$, quantified using the acidbase titration. The polynomial equation milliequivalents (meq) of acid (-value) or base (+value) per $\mathrm{L}$ of substrate $=0.8780 \times \Delta \mathrm{pH}^{3}+1.3369 \times \Delta \mathrm{pH}^{2}+9.9856 \times \Delta \mathrm{pH}-0.2569$, with $P<0.0001$. 
mass. Nutrient uptake was calculated by subtracting the average nutrient mass for four seedlings from the nutrient mass of each replicate. The uptake of nutrients was converted to meq values for calculating net ion uptake and cation or anion uptake ratio.

Net ion uptake was calculated as meq total of anions minus cations taken up and cation or anion uptake ratio was calculated as meq of total cation divided by total anion uptake for plants supplied with 0:100 solution. Assumed forms of ions taken up by roots were $\mathrm{NO}_{3}^{-}, \mathrm{H}_{2} \mathrm{PO}_{4}^{-}, \mathrm{SO}_{4}{ }^{2-}, \mathrm{MoO}_{4}{ }^{2-}$, and $\mathrm{Cl}^{-}$for anions and $\mathrm{K}^{+}, \mathrm{Ca}^{2+}, \mathrm{Mg}^{2+}, \mathrm{Fe}^{2+}, \mathrm{Mn}^{2+}, \mathrm{Cu}^{2+}$, $\mathrm{Zn}^{2+}, \mathrm{Na}^{+}$, and $\mathrm{Al}^{3+}$ for cations. Boron was not considered in cation and anion calculations because $\mathrm{H}_{3} \mathrm{BO}_{3}{ }^{0}$ is taken up as an uncharged molecule below pH 7.0 (Marschner, 2012; Miwa and Fujiwara, 2010). For each species, net ion uptake was divided by the total dry mass gain (grams) to determine the net uptake per unit of plant growth. Species-estimated meq of acid or base produced per volume of container substrate $(350 \mathrm{~mL})$ was also divided by the total dry mass gain to determine the estimated meq of acid or base per unit of plant growth. Individual cation or anion uptake was calculated as a percentage of total cation or total anion uptake, respectively.

PROC GLM ANOVA in SAS 9.4 (SAS Institute, Cary, NC) was used to evaluate floriculture species and solution $\mathrm{NH}_{4}{ }^{+}: \mathrm{NO}_{3}{ }^{-}$ ratio main and interaction effects on substrate-pH, dry mass gain, and meq of acid or base produced per gram of dry mass gain. ANOVA with PROC GLM was also used to evaluate species main effects on cation or anion uptake ratio, net meq of anions minus cations taken up, meq anions minus cations taken up per gram of dry mass gain, meq of individual nutrients taken up, and $\mathrm{Fe}^{2+}$ and $\mathrm{Mn}^{2+}$ concentration in tissue for plants supplied the 0:100 solution. Linear regression was used to calculate the $\mathrm{NH}_{4}^{+}: \mathrm{NO}_{3}{ }^{-}$expected to result in a stable $\mathrm{pH}$ for each species, where percent $\mathrm{NH}_{4}{ }^{+}-\mathrm{N}$ of total $\mathrm{N}$ supplied with each of the three solution types and meq of acid or base produced per container volume of substrate $(350 \mathrm{~mL})$ were independent and dependent variables, respectively. PROC FASTCLUS $k$-means cluster analysis was used in combination with PROC FREQ to separate species into three clusters that corresponded to the species about acidic, intermediate, and basic effects on substrate$\mathrm{pH}$. Clusters were based on the percent $\mathrm{NH}_{4}{ }^{+}-\mathrm{N}$ of total $\mathrm{N}$ estimated for a stable $\mathrm{pH}$, the mean values for meq of acid or base produced per gram of dry mass gain for each of the three solution types, meq of anions minus cations taken up per gram of dry mass gain ( $0: 100$ solution), and cation or anion uptake ratio (0:100 solution) for each species. ANOVA with PROC GLM was used to evaluate the differences between the three groups for each variable used in clustering. Tukey's honestly significant difference at $\alpha=0.05$ significance level was used for mean separation.

\section{Results and Discussion}

Final substrate-pH was affected by plant species $(P<0.0001)$, solution $\mathrm{NH}_{4}{ }^{+}: \mathrm{NO}_{3}{ }^{-}$ ratio $(P<0.0001)$, and their interaction $(P<$ 0.0001 ), and ranged from 4.83 to 6.58 between species and solution types (Fig. 1). When fertilized with the $0: 100 \mathrm{NH}_{4}{ }^{+}: \mathrm{NO}_{3}{ }^{-}$ solution, 13 species resulted in final substrate$\mathrm{pH}$ greater than the initial $\mathrm{pH}$ of 5.84. When fertilized with the 40:60 $\mathrm{NH}_{4}{ }^{+}: \mathrm{NO}_{3}{ }^{-}$solution, all 15 species resulted in final substrate-pH lower than the initial $\mathrm{pH}$. Substrate-pH leastsquare means were $6.24,5.75$, and 5.25 for the $0: 100,20: 80$, and 40:60 $\mathrm{NH}_{4}{ }^{+}: \mathrm{NO}_{3}^{-}$solutions, respectively.
Species effects on substrate-pH can be compared on the basis of the meq of acidity or basicity produced per gram of plant growth (NMEQ). For example, Rengel (2003) showed that 37 agronomic species differed in NMEQ, ranging from 0.3 to $2.0 \mathrm{meq}$ of acidity produced per gram of shoot dry mass (original reported units were centimoles of acid per kilogram of shoot dry mass). To calculate NMEQ, plant growth was measured as the change in total dry mass over $33 \mathrm{~d}$, which differed by species $(P<0.0001)$ but not by $\mathrm{NH}_{4}{ }^{+}: \mathrm{NO}_{3}^{-}$ratio $(P=0.8018)$ (data not shown). In addition, change in substrate$\mathrm{pH}$ over time was converted to units of meq of acid and base produced in the substrate

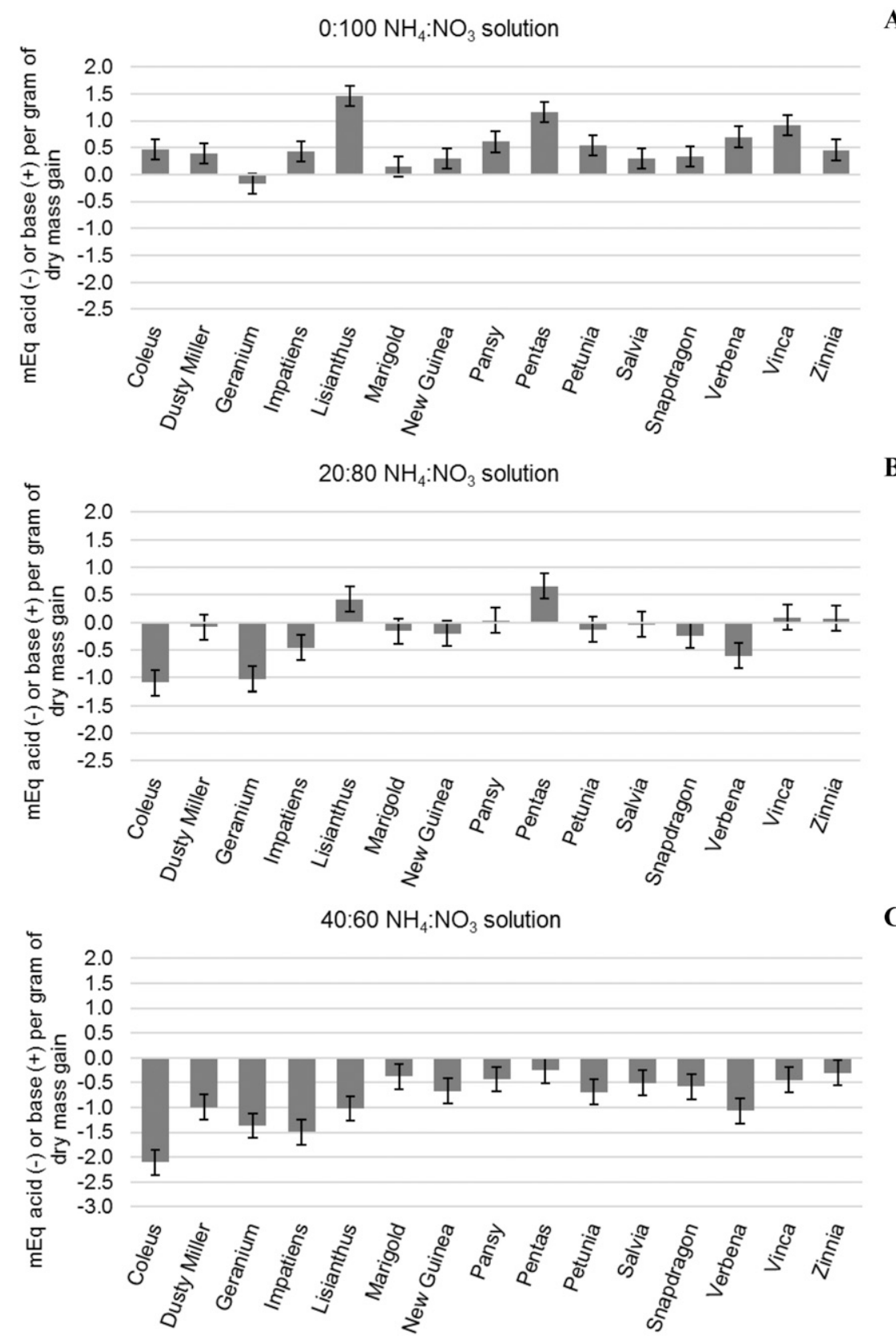

Fig. 3. Milliequivalents (meq) of acid or base per gram of plant dry mass gain after $33 \mathrm{~d}$ for floriculture species grown in peat:perlite substrate irrigated with nutrient solutions containing $100 \mathrm{mg} \cdot \mathrm{L}^{-1} \mathrm{~N}$ and $\mathrm{NH}_{4}{ }^{+}: \mathrm{NO}_{3}{ }^{-}$nitrogen ratios of (A) 0:100, (B) 20:80, and (C) 40:60. Data represent species least-square means of six replicates. Error bars are $\pm 95 \%$ confidence intervals using Tukey's honestly significant difference at $\alpha=0.05$. 
Table 1. Species main effects on milliequivalents (meq) net anions minus cations taken up, meq net anions minus cations taken up per gram of dry mass gain, and meq of acid or base produced per gram of dry mass gain when supplied 0:100 solution. Data are species least-square means of six replicates. Mean separation used Tukey's honestly significant difference at $\alpha=0.05$. Percent $\mathrm{NH}_{4}{ }^{-}-\mathrm{N}$ of total $\mathrm{N}$ expected for a stable pH was calculated for each species using linear regression based on species meq of acid or base produced per container volume of substrate (dependent variable) and percent $\mathrm{NH}_{4}{ }^{+}-\mathrm{N}$ of total $\mathrm{N}_{\text {supplied for }}$ each of the three nutrient solution (independent variable).

\begin{tabular}{|c|c|c|c|c|c|}
\hline Plant species & $\begin{array}{l}\text { meq anions minus } \\
\text { cations taken up }\end{array}$ & $\begin{array}{c}\text { Cation or anion uptake } \\
\text { ratio }\end{array}$ & $\begin{array}{c}\text { meq anions minus cations } \\
\text { taken up per gram dry } \\
\text { mass gain }\end{array}$ & $\begin{array}{c}\text { meq acid }(-) \text { or base } \\
(+) \text { per gram dry mass gain }\end{array}$ & Neutral $(\%) \mathrm{NH}_{4}{ }^{+}-\mathrm{N}$ \\
\hline Coleus & $0.87 \mathrm{~b}$ & $0.75 \mathrm{ab}$ & $0.90 \mathrm{abc}$ & 0.47 cde & 4.4 \\
\hline Dusty Miller & $1.85 \mathrm{ab}$ & $0.78 \mathrm{ab}$ & $0.59 \mathrm{abc}$ & $0.39 \mathrm{de}$ & 14.0 \\
\hline Geranium & $0.88 \mathrm{~b}$ & $0.85 \mathrm{a}$ & $0.42 \mathrm{c}$ & $-0.07 \mathrm{f}$ & $0.0^{\mathrm{z}}$ \\
\hline Impatiens & $2.20 \mathrm{ab}$ & $0.73 \mathrm{ab}$ & $0.91 \mathrm{abc}$ & $0.43 \mathrm{de}$ & 9.3 \\
\hline Lisianthus & $3.47 \mathrm{ab}$ & $0.48 \mathrm{c}$ & $1.69 \mathrm{a}$ & $1.47 \mathrm{a}$ & 25.4 \\
\hline Marigold & $2.71 \mathrm{ab}$ & $0.82 \mathrm{ab}$ & $0.38 \mathrm{bc}$ & 0.15 ef & 11.2 \\
\hline New Guinea Impatiens & $2.28 \mathrm{ab}$ & $0.76 \mathrm{ab}$ & $0.63 \mathrm{abc}$ & $0.30 \mathrm{def}$ & 11.5 \\
\hline Pansy & $3.44 \mathrm{ab}$ & $0.65 \mathrm{abc}$ & $1.03 \mathrm{abc}$ & $0.61 \mathrm{cde}$ & 22.9 \\
\hline Pentas & $1.90 \mathrm{ab}$ & $0.67 \mathrm{abc}$ & $0.70 \mathrm{abc}$ & $1.16 \mathrm{ab}$ & 35.1 \\
\hline Petunia & $2.55 \mathrm{ab}$ & $0.75 \mathrm{ab}$ & $0.90 \mathrm{abc}$ & $0.55 \mathrm{cde}$ & 16.4 \\
\hline Salvia & $2.50 \mathrm{ab}$ & $0.78 \mathrm{ab}$ & $0.61 \mathrm{abc}$ & $0.31 \mathrm{def}$ & 15.1 \\
\hline Snapdragon & $2.44 \mathrm{ab}$ & $0.69 \mathrm{abc}$ & $0.84 \mathrm{abc}$ & $0.34 \mathrm{de}$ & 13.6 \\
\hline Verbena & $2.64 \mathrm{ab}$ & $0.66 \mathrm{abc}$ & $1.51 \mathrm{a}$ & $0.70 \mathrm{bcd}$ & 13.4 \\
\hline Vinca & $3.73 \mathrm{a}$ & $0.58 \mathrm{bc}$ & $1.22 \mathrm{abc}$ & $0.92 \mathrm{bc}$ & 25.9 \\
\hline Zinnia & $1.51 \mathrm{ab}$ & $0.84 \mathrm{a}$ & $0.34 \mathrm{bc}$ & $0.46 \mathrm{cde}$ & 24.5 \\
\hline Significance level & $* * *$ & $* * *$ & $* * *$ & $* * *$ & \\
\hline
\end{tabular}

**** Indicates a significance level of $P<0.0001$.

${ }^{\mathrm{z}} \mathrm{A}$ negative percent $\mathrm{NH}_{4}^{+}-\mathrm{N}$ of total $\mathrm{N}$ value was predicted for geranium for a neutral $\mathrm{pH}$. Therefore, $0 \% \mathrm{NH}_{4}^{+}-\mathrm{N}$ would be required to minimize acidity.

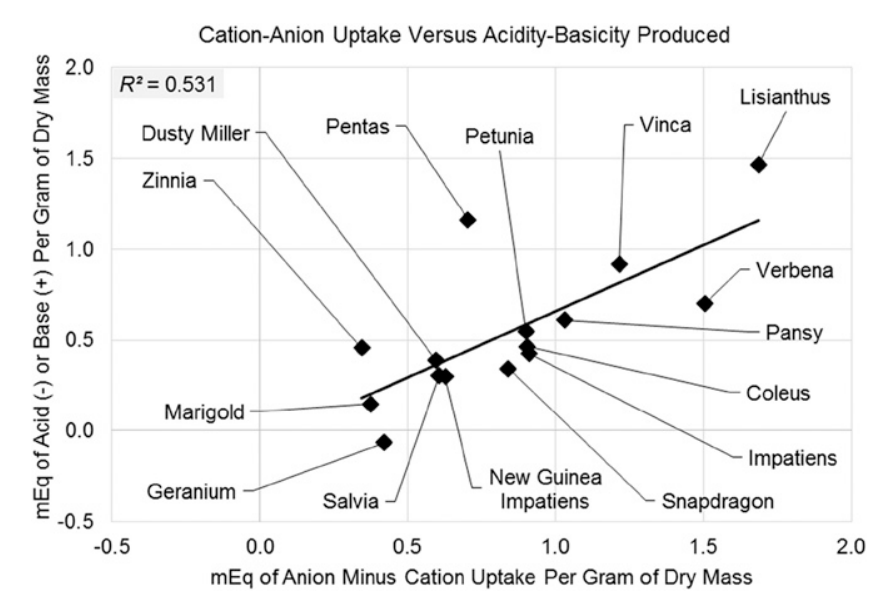

Fig. 4. Relationship between milliequivalents (meq) net cation or anion uptake (shown as meq anions minus cations taken up) and meq acid or base produced per gram of dry mass increase for species fertilized with the 0:100 solution. Data represent least-square means of six replicates. The regression equation is meq acid or base produced per gram dry mass increase $=0.725 \pm 0.408 *$ (meq anion minus cation uptake per gram dry mass increase) $-0.066 \pm 0.377$ with $R^{2}=0.531$.

using an acid-base titration (Johnson et al., 2010). In a laboratory procedure, meq of acid $(\mathrm{HCl})$ and base (hydrated dolomitic limestone) applied to samples of substrate was correlated with change in $\mathrm{pH}$ units (from initial pH 5.84). Substrate-pH decreased as much as 3.34 units when titrated with acid and increased as much as 2.58 units when titrated with base (Fig. 2). A polynomial response curve was generated and used to estimate meq of acid (negative values) and base (positive values) produced per $\mathrm{L}$ of substrate corresponding to a specific change in $\mathrm{pH}$ units. For example, a substrate-pH change of $-1 \mathrm{pH}$ units would equal -9.72 meq (acid) using the equation in Fig. 2. Initial substrate-pH (5.84) was subtracted from final values in Fig. 1 to determine change in $\mathrm{pH}$ units, which were converted to meq of acid or base produced per L of substrate. Acid or base (meq) per L of substrate was scaled to the volume of substrate per replicate $(350 \mathrm{~mL})$ for meq of acid or base produced per container and divided by total dry mass gain for meq of acid or base produced per unit of growth.

There was an interaction between species and $\mathrm{NH}_{4}{ }^{+}: \mathrm{NO}_{3}{ }^{-}$ratio $(P<0.0001)$ on NMEQ. The NMEQ of acid (negative value) or base (positive value) ranged between species and solution types from $1.47 \mathrm{meq}$ of base for lisianthus (0:100 solution) to $-2.10 \mathrm{meq}$ of acid for coleus (40:60 solution) (Fig. 3). In the $0: 100$ solution, geranium and marigold produced an NMEQ not different from zero, whereas other species produced base up to $1.47 \mathrm{meq}$ of base for lisianthus (Fig. 3A). These levels of NMEQ are similar to the $0.3-2.0$ of acidity reported by Rengel (2003) in field soil conditions with an unspecified fertilizer regime. In the 20:80 solution, pentas and lisianthus were the only species to produce base (Fig. 3B). Most species produced acid in the 40:60 solution, except for pentas which was not different from zero (Fig. 3C). Although commercial watersoluble fertilizers are labeled as "acidic," "neutral," or "basic" in their effects on $\mathrm{pH}$ based on calcium carbonate equivalents (Pierre, 1933), results in Fig. 3 show that fertilizer effects on substrate-pH depend on the plant species grown.

Past research has shown that plants fertilized with $100 \% \mathrm{NO}_{3}{ }^{-}-\mathrm{N}$ typically have net anion uptake (shown as a positive meq anions minus cations per gram of dry mass gain) and cation or anion uptake ratios less than 1 (Haynes, 1990; Kirkby and Knight, 1977; Marschner, 2012). To calculate net anion uptake, the uptake of individual nutrients per gram of dry mass gain was first analyzed using ANOVA for each species in the 0:100 solution. There were species differences $(P<$ $0.01)$ for all macronutrients, sodium, and chloride (data not shown). Uptake of cations and anions was dominated by $\mathrm{NO}_{3}^{-}$, which contributed between $38.0 \%$ and $43.8 \%$ of the total (meq) combined cations and anions. As a contribution of total meq of anion uptake, $\mathrm{NO}_{3}{ }^{-}(75.9 \%$ to $87.3 \%)$ was followed by $\mathrm{H}_{2} \mathrm{PO}_{4}^{-}$(4.4\% to $9.2 \%$ depending on species), $\mathrm{SO}_{4}^{2-}(3.3 \%$ to $14.2 \%)$, and $\mathrm{Cl}^{-}(1.5 \%$ to $6.7 \%$ ). Cations taken up were predominantly $\mathrm{K}^{+}(28.0 \%$ to $59.2 \%$ of total cations $), \mathrm{Ca}^{2+}$ ( $10.8 \%$ to $40.6 \%), \mathrm{Mg}^{2+}(19.6 \%$ to $36.6 \%)$, and $\mathrm{Na}^{+}(0.7 \%$ to $6.7 \%)$. Micronutrients represented $<1 \%$ of total uptake. When the meq of all cations was subtracted from meq of all anions, the net anion uptake was lowest for zinnia $\left(0.34 \mathrm{meq} \cdot \mathrm{g}^{-1}\right)$ and greatest for lisianthus (1.69 meq. $\left.\mathrm{g}^{-1}\right)$, and the ratio of cations or anions taken up into plant tissue ranged from 0.48 (lisianthus) to 0.85 (geranium) (Table 1). The observed trend, whereby all plants took up more anions than cations in the 0:100 solution, was consistent with published studies by Kirkby and Knight 
Table 2. Species listed by cluster (numbers one through three) from $k$-means cluster analysis with cluster main effects on percent $\mathrm{NH}_{4}{ }^{+}-\mathrm{N}$ of total $\mathrm{N}$ for a neutral $\mathrm{pH}$ effect, milliequivalents (meq) of acid and base per gram of dry mass gain for each of the three solution types (0:100, 20:80, 40:60), meq anions minus cations taken up per gram of dry mass gain with species supplied 0:100 solution, and cation or anion uptake ratio with species supplied 0:100 solution. Species were clustered based on each species percent estimated $\mathrm{NH}_{4}{ }^{+}-\mathrm{N}$ of total $\mathrm{N}$ for stable $\mathrm{pH}$ and mean values $(n=6)$ for each of the remaining variables. Data represent cluster least-square means of two (cluster 1), eight (cluster 2), and five (cluster 3) species. Mean separation used Tukey's honestly significant difference at $\alpha=0.05$.

\begin{tabular}{|c|c|c|c|c|c|c|c|}
\hline \multirow[b]{2}{*}{ Plant species } & \multirow{2}{*}{$\begin{array}{l}\text { Cluster } \\
\text { number }\end{array}$} & \multirow{2}{*}{$\begin{array}{l}\text { Cluster neutral \% } \\
\qquad \mathrm{NH}_{4}^{+}-\mathrm{N}^{\mathrm{z}}\end{array}$} & \multicolumn{3}{|c|}{$\begin{array}{l}\text { meq of acid }(-) \text { or base }(+) \\
\text { per gram of dry mass gain }\end{array}$} & \multirow{2}{*}{$\begin{array}{l}\text { meq anions minus cations } \\
\text { taken up per gram dry } \\
\text { mass gain }\end{array}$} & \multirow{2}{*}{$\begin{array}{l}\text { Cation/anion } \\
\text { uptake ratio }\end{array}$} \\
\hline & & & $0: 100$ & $20: 80$ & $40: 60$ & & \\
\hline $\begin{array}{l}\text { Geranium } \\
\text { Coleus }\end{array}$ & 1 & $0 \% \mathrm{c}$ & $0.16 \mathrm{~b}$ & $-1.06 \mathrm{c}$ & $-1.73 \mathrm{~b}$ & $0.40 \mathrm{a}$ & $0.80 \mathrm{a}$ \\
\hline $\begin{array}{l}\text { Dusty Miller } \\
\text { Impatiens } \\
\text { Marigold } \\
\text { New Guinea Impatiens } \\
\text { Petunia } \\
\text { Salvia } \\
\text { Snapdragon } \\
\text { Verbena }\end{array}$ & 2 & $13.1 \% \mathrm{~b}$ & $0.40 \mathrm{~b}$ & $-0.24 b$ & $-0.80 \mathrm{a}$ & $0.80 \mathrm{a}$ & $0.75 \mathrm{a}$ \\
\hline $\begin{array}{l}\text { Lisianthus } \\
\text { Pansy } \\
\text { Pentas } \\
\text { Vinca } \\
\text { Zinnia }\end{array}$ & 3 & $26.8 \% \mathrm{a}$ & $0.92 \mathrm{a}$ & $0.26 \mathrm{a}$ & $-0.49 \mathrm{a}$ & 0.99 a & $0.64 \mathrm{a}$ \\
\hline Significance level & & $* * *$ & $*$ & $* * *$ & $* *$ & NS & NS \\
\hline
\end{tabular}

Ns, ${ }^{*},{ }^{* *},{ }^{* * *}$ Indicate a significance level of not significant, $P<0.05, P<0.01$, and $P<0.0001$, respectively.

${ }^{\mathrm{z}}$ An average negative percent $\mathrm{NH}_{4}^{+}-\mathrm{N}$ of total $\mathrm{N}$ value $(>-1)$ was predicted for geranium and coleus $($ cluster 1$)$. Therefore, $0 \% \mathrm{NH}_{4}{ }^{-}-\mathrm{N}$ would be needed to minimize acidity and provide a near stable $\mathrm{pH}$.

Table 3. Species listed by cluster (numbers one through three) from $k$-means cluster analysis with species main effects on tissue concentrations of $\mathrm{Fe}^{2+}$ and $\mathrm{Mn}^{2+}$ when supplied with 0:100 solution. Data are least-square means of six replicates. Mean separation used Tukey's honestly significant difference at $\alpha=0.05$.

\begin{tabular}{lccc}
\hline Plant species & Cluster & Tissue Fe $\left(\mu \mathrm{g}^{-1}\right.$ dry tissue $)$ & Tissue $\mathrm{Mn}^{-} \mu \mathrm{g}^{\left.-\mathrm{g}^{-1} \mathrm{dry} \text { tissue }\right)}$ \\
\hline Geranium & 1 & $85.2 \mathrm{c}$ & $97.0 \mathrm{bcde}$ \\
Coleus & & $144.4 \mathrm{c}$ & $99.3 \mathrm{bcd}$ \\
Dusty Miller & 2 & $172.1 \mathrm{c}$ & $83.6 \mathrm{cdef}$ \\
Impatiens & $104.8 \mathrm{c}$ & $82.2 \mathrm{cdef}$ \\
Marigold & $476.8 \mathrm{a}$ & $67.2 \mathrm{fg}$ \\
New Guinea Impatiens & & $117.1 \mathrm{c}$ & $61.1 \mathrm{fg}$ \\
Petunia & $88.3 \mathrm{c}$ & $80.1 \mathrm{cdef}$ \\
Salvia & $150.1 \mathrm{c}$ & $104.7 \mathrm{abc}$ \\
Snapdragon & $89.5 \mathrm{c}$ & $68.7 \mathrm{fg}$ \\
Verbena & $156.3 \mathrm{c}$ & $76.4 \mathrm{defg}$ \\
Lisianthus & $147.7 \mathrm{c}$ & $52.0 \mathrm{~g}$ \\
Pansy & $87.8 \mathrm{c}$ & $112.2 \mathrm{ab}$ \\
Pentas & & $127.4 \mathrm{c}$ & $73.1 \mathrm{efg}$ \\
Vinca & 3 & $106.3 \mathrm{c}$ & $75.4 \mathrm{defg}$ \\
Zinnia & $300.0 \mathrm{~b}$ & $128.8 \mathrm{a}$ \\
Significance level & $* * *$ & $* * *$ \\
\hline
\end{tabular}

*** Indicates a significance level of $P<0.0001$.

(1977) with hydroponically grown tomatoes in a nutrient solution with $100 \% \mathrm{NO}_{3}-\mathrm{N}$. A positive correlation was found between net anion uptake (based on tissue analysis) and NMEQ (based on substrate-pH change) when fertilized with $100 \% \mathrm{NO}_{3}^{-}-\mathrm{N}$ (Fig. 4). Similarly, Rengel (2003) found that meq of acid produced by roots (NMEQ) was correlated with meq of excess cations taken up into plant tissue for 37 agronomic crop species grown in field soil.

The $\mathrm{NH}_{4}{ }^{+}: \mathrm{NO}_{3}{ }^{-}$ratios estimated to result in a neutral $\mathrm{pH}$ effect were calculated for each species using linear regression (Table 1). The percent $\mathrm{NH}_{4}{ }^{+}-\mathrm{N}$ of total $\mathrm{N}$ applied in the three nutrient solutions and meq of acid or base per $\mathrm{L}$ of substrate over $33 \mathrm{~d}$ were independent and dependent variables, respectively. $R^{2}$ values were above 0.730 and averaged 0.856 for all species (data not shown). With the exception of geranium, species were estimated to require between $4.4 \%$ (coleus) and $35.1 \%$ (pentas) of total $\mathrm{N}$ as $\mathrm{NH}_{4}{ }^{+}-\mathrm{N}$ with the remainder of $\mathrm{N}_{\text {as }} \mathrm{NO}_{3}{ }^{-} \mathrm{N}$ to balance species and nitrogen effects and result in zero $\mathrm{pH}$ change over time (Table 1 ). Geranium produced meq of acid not different from zero when fertilized with the 0:100 solution, resulting in a negative predicted $\mathrm{NH}_{4}{ }^{+}: \mathrm{NO}_{3}{ }^{-}$ratio, and therefore would require fertilization with $100 \% \quad \mathrm{NO}_{3}{ }^{-}-\mathrm{N}$ to minimize acidity. On average, species required greater $\mathrm{NH}_{4}^{+}: \mathrm{NO}_{3}{ }^{-}$ratios for a neutral effect compared with the observations made by Sonneveld and Voogt (2009), who reported that most greenhouse crop species require $\mathrm{NH}_{4}{ }^{+}-\mathrm{N}$ between $5 \%$ and $10 \%$ of total $\mathrm{N}$ for a stable $\mathrm{pH}$ in soilless substrates.

In commercial horticulture production of diverse crops, it is not practical to have a specific fertilizer formulation to stabilize $\mathrm{pH}$ for each species. One possibility is to separate species into groups and manage $\mathrm{pH}$ for each group separately. Cluster analysis in combination with ANOVA was therefore used to determine grouping of species with similar effects on $\mathrm{pH}$.

Species were separated into three clusters using $k$-means cluster analysis, using the neutral percent $\mathrm{NH}_{4}^{+}-\mathrm{N}$ of total $\mathrm{N}, \mathrm{NMEQ}$ for each of the three solutions, net anion uptake in the $0: 100$ solution, and cation or anion uptake ratio in the $0: 100$ solution as dependent variables. The contribution of each variable in terms of separating species into clusters was shown by the cluster analysis $R^{2}$ values. The $R^{2}$ equaled 0.871 for the neutral percent $\mathrm{NH}_{4}{ }^{+}-\mathrm{N}$ of total $\mathrm{N}, R^{2}=0.530$ for NMEQ in $0: 100, R^{2}=0.816$ for NMEQ in $20: 80, R^{2}=0.580$ for NMEQ in 40:60, $R^{2}=0.179$ for net anion uptake, and $R^{2}=0.334$ for cation or anion uptake ratio. Therefore, clusters differed more consistently in the neutral percent $\mathrm{NH}_{4}{ }^{+}-\mathrm{N}$ of total $\mathrm{N}$ than in other variables. Clusters were compared by each variable using ANOVA, where clusters differed in percent $\mathrm{NH}_{4}{ }^{+}-\mathrm{N}$ of total $\mathrm{N}(P<$ $0.0001)$ and meq of acid or base per gram of dry mass gain in $0: 100(P=0.0108), 20: 80$ $(P<0.0001)$, and 40:60 $(P=0.0055)$ solution. There were no statistical differences for meq of anions minus cations taken up $(P=0.3054)$ or cation or anion balance $(P=0.0869)$ in $0: 100$ solution (Table 2). 
Species are summarized by cluster in Table 2. On average, species in cluster 1 had the greatest mean meq acid per gram of dry mass gain whereas species in cluster 3 had the greatest mean meq of base per gram of dry mass gain for each of the three solution types (Table 2), and overall were acidic and basic in effects on $\mathrm{pH}$. For meq of acid or base (per gram of dry mass gain), species in cluster 2 were not different from cluster 1 in 0:100 solution or cluster 3 in 40:60 solution but differed from both clusters with 20:80 solution and were considered as intermediate in effects on $\mathrm{pH}$. Each cluster differed in species mean percent $\mathrm{NH}_{4}{ }^{+}-\mathrm{N}$ expected to stabilize $\mathrm{pH}$, averaging $0 \%, 13.1 \%$, and $26.8 \% \mathrm{NH}_{4}{ }^{+}-\mathrm{N}$ of total $\mathrm{N}$ for clusters 1,2 , and 3 , respectively (Table 2). Supplying species clustered as acidic, intermediate, and basic with $\approx 0 \%, 13 \%$, and $27 \%$ of total $\mathrm{N}$ as $\mathrm{NH}_{4}^{+}-\mathrm{N}$, respectively, would be expected to result in about stable substrate-pH across species.

Tendency to decrease root zone $\mathrm{pH}$ is a potential strategy used by some ironefficient species to increase iron solubility and uptake (Marschner, 2012). Iron solubility is reduced as substrate-pH increases (Lindsay, 1979). Crop species are labeled as ironefficient if they exhibit root strategies that specifically increase iron uptake, such as acidifying the rhizosphere, efflux of organic acids and chelating molecules, and greater ability to reduce iron at root surfaces (Bienfait, 1988; Marschner, 2012). Albano and Miller (1996) found that marigold responded to low substrate-iron concentration by acidifying the root zone and increasing iron reductase activity, which are iron-efficiency strategies. Albano and Miller (1996) also found that under iron-sufficient and excess conditions, root zone acidification and increased iron reductase activity was not expressed. Floriculture species that have been noted to decrease $\mathrm{pH}$ include geranium and marigold (Gibson et al., 2007; Johnson et al., 2013). Floriculture species that are susceptible to iron or manganese toxicity symptoms at low substrate-pH include geranium, marigold, lisianthus, pentas, and New Guinea impatiens (Argo and Fisher, 2002; Harbaugh, 1995; Whipker et al., 2003). However, this group of species sensitive to low substrate$\mathrm{pH}$ differed considerably in this study in their effects on pH (Figs. 1 and 3). For example, lisianthus and pentas had among the most basic $\mathrm{pH}$ effects in this study (Fig. 3). Floriculture species sensitive to high $\mathrm{pH}$ and iron or manganese deficiency include pansy, petunia, salvia, snapdragon, vinca, and zinnia (Cavins et al., 2000; Gibson et al., 2007). Pansy, petunia, and vinca have also been noted to increase pH (Gibson et al., 2007; Johnson et al., 2013). Vinca, pansy, and zinnia in this experiment were considerably more basic compared with petunia, salvia, and snapdragon (Fig. 3). Categorizing species response in terms of susceptibility to micronutrient toxicity or deficiency at low or high $\mathrm{pH}$ therefore differs from the effect of species on substrate-pH, which was quantified in this study.

Accumulation of $\mathrm{Fe}^{2+}$ and $\mathrm{Mn}^{2+}$ in tissue was not related to species acid-base cluster (Table 3). As previously mentioned, marigold and geranium are susceptible to iron or manganese toxicity whereas zinnia and pansy are susceptible to iron or manganese deficiency (Albano et al., 1996; Argo and Fisher, 2002; Gibson et al., 2007). However, marigold and zinnia had the greatest tissue concentration of $\mathrm{Fe}^{2+}$ whereas geranium and pansy had the lowest concentration. Tissue concentration of $\mathrm{Mn}^{2+}$ was also greatest in zinnia and lowest in lisianthus (susceptible to iron or manganese toxicity). Differential uptake of individual macronutrients affects species cation or anion uptake balance and consequently the effect on root zone $\mathrm{pH}$ (Bekele et al., 1983; Haynes, 1990; Marschner, 2012). In addition, total tissue iron analysis does not differentiate between biologically active and inactive forms within plant cells, where high proportions of inactive iron have been linked with symptoms of iron deficiency in leaves (Marschner, 2012).

\section{Conclusions}

The acidic and basic effects of plants on substrate-pH were quantified over a wide range of floriculture container crop species. When supplied with $100 \% \mathrm{NO}_{3}{ }^{-} \mathrm{N}$, species with greater net anion uptake produced greater basicity in the substrate compared with species with greater cation uptake. Commercial growers can adjust the ratio of $\mathrm{NH}_{4}{ }^{+}-\mathrm{N}$ and $\mathrm{NO}_{3}{ }^{-}-\mathrm{N}$ in the applied water-soluble fertilizer to balance species acidic or basic effects and stabilize $\mathrm{pH}$ over time. Percent $\mathrm{NH}_{4}{ }^{+}-\mathrm{N}$ of total $\mathrm{N}$ supplied estimated to result in a stable $\mathrm{pH}$ ranged from $0 \%$ (geranium) to $35 \%$ (pentas) across species. However, it is not practical to supply a specific fertilizer formulation to stabilize $\mathrm{pH}$ for each species in commercial production. Using a $k$-means clustering and statistical approach, species in this study were separated into groups that corresponded to species about acidic, intermediate, and basic effects on substrate-pH. Supplying 0\%, 13\%, and 27\% of total $\mathrm{N}$ as $\mathrm{NH}_{4}^{+}-\mathrm{N}$ (remainder as $\mathrm{NO}_{3}{ }^{-}-\mathrm{N}$ ) would result in about stable $\mathrm{pH}$ for acidic, intermediate, and basic species. Growers can group floriculture species by their tendency to increase or decrease substrate-pH and adjust the fertilizer $\mathrm{NH}_{4}{ }^{+}: \mathrm{NO}_{3}{ }^{-}$for each group as a strategy to manage $\mathrm{pH}$ and reduce the risk of micronutrient disorders.

Floriculture species that are reportedly susceptible to micronutrient toxicity at low $\mathrm{pH}$ did not all exhibit the iron-efficiency strategy of acidifying the rhizosphere $\mathrm{pH}$. For example, geranium was acidic and tended to decrease $\mathrm{pH}$, whereas lisianthus and pentas had among the most basic effects on substrate-pH. In addition, accumulation of $\mathrm{Fe}^{2+}$ and $\mathrm{Mn}^{2+}$ in plant tissue was not related to the measured species effects on substrate-pH or reported susceptibility to micronutrient toxicity or deficiency. For example, marigold (susceptible to iron or manganese toxicity) and zinnia (susceptible to iron or manganese deficiency) had the greatest tissue concentration of $\mathrm{Fe}^{2+}$ whereas geranium (susceptible to iron or manganese toxicity) and pansy (susceptible to iron or manganese deficiency) had the lowest concentration.

\section{Literature Cited}

Albano, J.P. and W.B. Miller. 1996. Iron deficiency stress influences physiology of iron acquisition in marigold (Tagetes erecta L.). J. Amer. Soc. Hort. Sci. 121:438-441.

Albano, J.P., W.B. Miller, and M.C. Halbrooks. 1996. Iron toxicity stress causes bronze speckle, a specific physiological disorder of marigold (Tagetes erecta L.). J. Amer. Soc. Hort. Sci. 121:430-437.

Argo, W.R. and J.A. Biernbaum. 1996. The effect of lime, irrigation-water source, and watersoluble fertilizer on root-zone $\mathrm{pH}$, electrical conductivity, and macronutrient management of container root media with impatiens. J. Amer. Soc. Hort. Sci. 121:442-452.

Argo, W.R. and J.A. Biernbaum. 1997. Lime, water source, and fertilizer nitrogen form affect medium $\mathrm{pH}$ and nitrogen accumulation and uptake. HortScience 32:71-74.

Argo, W.R. and P.R. Fisher. 2002. Understanding $\mathrm{pH}$ management for container-grown crops. Meister Publishing, Willoughby, $\mathrm{OH}$.

Barnes, J., P. Nelson, B.E. Whipker, D.A. Dickey, D. Hesterberg, and W. Shi. 2014. Statistical model for describing macronutrient impacts on container substrate $\mathrm{pH}$ over time. HortScience 49:207-214.

Bekele, T., B.J. Cino, P.A.I. Ehlert, A.A. van der Mass, and A. van Diest. 1983. An evaluation of plant-borne factors promoting the solubilization of alkaline rock phosphates. Plant Soil 75:361-378.

Bienfait, H.F. 1988. Mechanisms in Fe-efficiency reactions of higher plants. J. Plant Nutr. 11:605-629.

Cavins, T.J., B.E. Whipker, W.C. Fonteno, B Harden, I. McCall, and J.L. Gibson. 2000. Monitoring and managing $\mathrm{pH}$ and EC using the PourThru extraction method. North Carolina State Univ. Hort. Info. Lflt. 590.

Dickson, R.W., P.R. Fisher, W.R. Argo, D.J. Jacques, J.B. Sartain, L.E. Trenholm, and T.H. Yeager. 2016. Solution ammonium:nitrate ratio and cation/anion uptake affect acidity or basicity with floriculture species in hydroponics. Sci. Hort. 200:36-44.

Engels, C. and H. Marschner. 1995. Plant uptake and utilization of nitrogen, p. 41-82. In: P.E. Bacon (ed.). Nitrogen fertilization in the environment. Marcel Dekker, Inc., New York, NY.

Gibson, J.L., D.S. Pitchay, A.L. Williams-Rhodes, B.E. Whipker, P.V. Nelson, and J.M. Dole. 2007. Nutrient deficiencies in bedding plants: A pictorial guide for identification and correction. Ball Publishing. Batavia, IL.

Harbaugh, B.K. 1995. Iron toxicity in Pentas lanceolata. HortTechnology 5:306-307.

Haynes, R.J. 1990. Active ion uptake and maintenance of cation-anion balance: A critical examination of their role in regulating rhizosphere pH. Plant Soil 126:247-264.

Hoagland, D.R. and D.I. Arnon. 1950. The water culture method for growing plants without soil Calif. Agr. Expt. Sta. Circ. 347.

Huang, J., P.V. Nelson, and J. Lee. 2001. Seedling effect on root substrate $\mathrm{pH}$. J. Plant Nutr. 24:1133-1147. 
Johnson, C.N., P.R. Fisher, J. Huang, R.P. Vetanovetz, and W.R. Argo. 2010. Quantifying the acidity of an ammonium-based fertilizer in containerized production. HortScience 45:10991105.

Johnson, C.N., P.R. Fisher, J. Huang, T.H. Yeager, T.A. Obreza, R.P. Vetanovetz, W.R. Argo, and A.J. Bishko. 2013. Effect of fertilizer potential acidity and nitrogen form on the $\mathrm{pH}$ response in a peat-based substrate with three floriculture species. Sci. Hort. 162:135-143.

Kirkby, E.A. and A.H. Knight. 1977. Influence of the level of nitrate nutrition on ion uptake and assimilation, organic acid accumulation, and cation-anion balance in whole tomato plants. Plant Physiol. 60:349-353.

Lang, H.J. and G.C. Elliot. 1991. Influence of ammonium:nitrate ratio and nitrogen concentration on nitrification activity in soilless potting media. J. Soc. Hort. Sci. 116:642-645.

Lea-Cox, J.D., G.W. Stutte, W.L. Berry, and R.M. Wheeler. 1996. Charge balance-A theoretical basis for modulating $\mathrm{pH}$ fluctuations in plant nutrient delivery systems. Life Support Biosph. Sci. 3:53-59.

Lindsay, W.L. 1979. Chemical equilibria in soils. The Blackburn Press, Caldwell, NJ.

Marschner, P. 2012. Mineral nutrition of higher plants. 3rd ed. Academic Press, San Diego, CA.

Miwa, K. and T. Fujiwara. 2010. Boron transport in plants: Co-ordinated regulation of transporters. Ann. Bot. 105:1103-1108.

Peterson, J.C. 1981. Modify your pH perspective. Florists' Rev. 169:34-3592-93.

Pierre, W.H. 1933. Determination of equivalent acidity and basicity of fertilizers. Ind. Eng. Chem. 5:229-234.

Puustjarvi, V. and R.A. Robertson. 1975. Physical and chemical properties, p. 23-38. In: D.W Robinson and J.G.D. Lamb (eds.). Peat in horticulture. Academic Press, London.

Rengel, Z. 2003. Handbook of soil acidity. Vol. 94 CRC Press, London.

Scoggins, H.L., D.A. Bailey, and P.V. Nelson. 2002. Efficacy of the press extraction method for bedding plant plug nutrient monitoring. HortScience 37:108-112.
Sonneveld, C. and W. Voogt. 2009. Plant nutrition of greenhouse crops. Springer, Dordrecht, The Netherlands.

Verburg, K., J. Braschkat, Z. Hockman, A.D. Moore, K.R. Helyar, M.E. Probert, J.N.G. Hargraves, and R.J. Simpson. 2003. Modeling acidification processes in agricultural systems, p. 135-187. In: Z. Rengel (ed.). Handbook of soil acidity. Marcel Dekker Inc., New York, NY.

Vetanovetz, R.P. 1996. Tissue analyses and interpretation, p. 197-220. In: D.W. Reed (ed.). Water, media, and nutrition for greenhouse crops. Ball Publishing, Batavia, IL.

von Wiren, N., A. Gojon, S. Chaillou, and D. Raper. 2001. Mechanisms and regulation of ammonium uptake in higher plants, p. 61-77. In: P.J. Lea and J.F. Morot-Gaudry (eds.). Plant nitrogen. Springer, New York, NY.

Whipker, B.E., T.J. Cavins, J.L. Gibson, J.M. Dole, P.V. Nelson, and W. Fonteno. 2003. Plant nutrition, p. 29-46. In: D. Hamrick (ed.). Ball redbook. Vol. 2. Ball Publishing, Batavia, IL. 